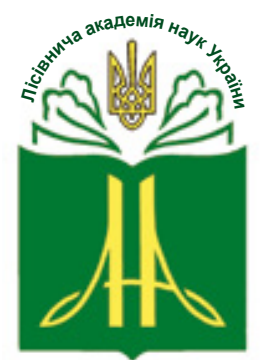

Forestry Academy of Sciences of Ukraine

Наукові праці Лісівничої академії наук України Proceedings of the Forestry Academy of Sciences of Ukraine

http://fasu.nltu.edu.ua https://doi.org/10.15421/411928

Article received 2019.03.11

Article accepted 2019.12.26
ISSN 1991-606X print

ISSN 2616-5015 online

(a) $\triangle$ Correspondence author

Viktor Tkach

Tkach@uriffm.org.ua

Pushkinska str., 86, Kharkiv, 61024, Ukraine

УДК $630 * 187: 630 * 22$

\title{
От создания классификации лесов как экосистем до формирования украинской школы лесной типологии (к 150-летию со дня рождения А. А. Крюденера)
}

\author{
В.П. Ткач', Е.С. Мигунова²
}

Понятие леса, как единства насаждения, климата и почвогрунта, т.е. как экосистемы впервые было определено А.А. Крюденером. Ученый разработал классификаиию лесов по плодородию почвогрунтов, на которых они произрастают, в координатах их обеспеченности элементами питания и влагой. А. А. Крюденер предложил первую экологическую классификацию лесов Европейской России по принципу районирования ее территории по основным климатическим показателям, с последующим разделением лесов в пределах климатических зон и областей на типы насаждений по особенностям петрографического состава и водного режима почвогрунтов.

Определяюшую роль в формировании типов насаждений внутри однородных в климатическом отношении территорий А. А. Крюденер, как и Г. Ф. Морозов, отводил почвенно-грунтовым условиям, подчеркивая при этом, что основополагающим фактором является не собственно почва как таковая, а почва как субстрат, как среда произрастания растений. Ученым, в процессе массового изучения почв разных типов леса, была выявлена тесная связь характера лесной растительности не с генетическими типами почв, а с их плодородием, с их лесорастительным потенциалом. При этом для оценки плодородия почв А.А. Крюденер использовал новый подход - метод фитоиндикации, то есть критерием качества почв им принята растительность, ее состав и производительность.

Суммарным показателем плодородия среды является количество, соотношение и распределение по сезонам года лимитированных экологических ресурсов - тепла, влаги и пищи. Лесотипологические классификачионные модели построены в координатах этих ресурсов - климатическая сетка в координатах тепла и атмосферного увлажнения, эдафическая - в координатах пищи и влаги почвогрунтов. Поэтому они применимы не только для классификации лесов, но и природы в иелом.

Охарактеризованы также основные достижения и вопросы сформировавщейся на этих приниипах украинской экологической школь лесной типологии. Отмечень имеющиеся проблемы, требуюшие дальнейшего решения.

Ключевые слова: лесная типология; экология; природа; классификачия; насаждения; климат; почвогрунты; плодородие.

\footnotetext{
Ткач Виктор Петрович - академик Лесной академии наук Украины, член-корреспондент НААН Украины, доктор сельскохозяйственных наук, профессор, директор. Украинский научно-исследовательский институт лесного хозяйства и агролесомелиорации им. Г.Н. Высоцкого, ул. Пушкинская, 86, Харьков, 61024, Украина. Тел.: (057) 704-10-02. E-mail: Tkach@uriffm.org.ua

2 Мигунова Елена Сергеевна - академик Лесной академии наук Украины, доктор сельскохозяйственных наук, профессор, главный научный сотрудник. Украинский научно-исследовательский институт лесного хозяйства и агролесомелиорации им. Г.Н. Высоцкого, ул. Пушкинская, 86, Харьков, 61024, Украина. Тел.: (057) 707-80-71. E-mail: migunova-e-s@yandex.ua
} 
Вступление. Артур Артурович Крюденер крупный государственный деятель России начала XX века, руководитель Лесного отдела Удельного управления, в ведении которого находилось более 7 млн га лучших лесных массивов России, принадлежавших царской семье, в том числе Беловежская пуща. В подведомственных ему лесах А. А. Крюденер вел очень интенсивное лесное хозяйство, начиная от детального лесоустройства до главных рубок. Наши известные лесоводы - акад. А. Б. Жуков и первый заведующий отделом лесных культур ВНИИЛМ'а П.П. Кожевников с гордостью вспоминали, что их отцы трудились под началом А. А. Крюденера.

В связи с тем, что имя этого выдающегося отечественного лесовода, эмигрировавшего в 1918 г. в Германию, долгие годы было предано забвению и потому недостаточно широко известно, мы приводим некоторые данные его биографии. Артур Артурович (позже в Германии - Артур Фрейгер) Крюденер родился 23 февраля 1869 г. в поместье РуженГроссхоф бывшей Лифляндии (ныне Эстония). Он происходил из знатной немецкой семьи, в течение многих поколений жившей в России и имевшей титул баронов, дарованный им Екатериной II. Представители этой семьи были крупными юристами, дипломатами, военачальниками. Артур Артурович избрал другую карьеру. Всю свою большую и сложную жизнь он посвятил служению горячо любимому им лесу. В 1894 г. он закончил Петербургский лесной институт и несколько лет работал таксатором в лесах России, многие из которых ранее никогда не обследовались. Впоследствии он писал: «От русского лесовода требуется не только весьма солидная естественно-научная подготовка, но и большой запас физических сил и редкое здоровье в борьбе со всеми невзгодами стихии и климата, в борьбе с теми лишениями, которые он среди лесной глуши испытывает на каждом шагу; от него требуется также сила духа и воли, железная энергия и главное любовь и преданность своему делу» [7, с. 5].

В 1901 г. А.А. Крюденер становится лесничим Петербургского удельного округа. Период работы в Управлении уделов (1901-1918 гг.), в ведении которого находились огромные сельскохозяйственные и лесные массивы в разных частях России, был очень плодотворным как для служебной карьеры, так и для научной деятельности А.А. Крюденера. Он руководил крупными лесоустроительными партиями, а в 1904-1910 гг. организовал и провел беспрецедентные по масштабам работы по составлению первых русских объемных и сортиментных таблиц, таблиц сбежистости и формы стволов всех основных древесных пород Европейской России. Группа специалистов под его руководством заложила в эти годы более 6 тысяч пробных площадей в лесах разных регионов России и обработала более 108 тысяч (!) модельных деревьев. Результаты этих работ опубликованы в двадцяти выпусках (Krüdener, 1908-1913). В каждом выпуске имеется очень содержательная характеристика древесной породы, которой он посвящен. Современники называли этот труд историческим. За него Крюденер получил высший в России гражданский чин действительного тайного советника, соответствующий воинскому званию маршала. Несколькими годами позже ему было поручено управление всеми лесами Удельного ведомства.

Результаты исследования. С первых лет производственной деятельности А.А. Крюденера ярко проявились его научные интересы. Ими были экология леса, изучение жизни леса во всем ее многообразии, обусловленном факторами внешней среды. А. А. Крюденер познакомился и подружился с проф. Г.Ф. Морозовым, который был вдохновителем и автором идеи типов насаждений. Эта идея сразу увлекла А.А. Крюденера. Он собрал огромный материал сопряженного изучения лесов разных типов и их почв. В отличие от большинства лесоводов того времени, рассматривавших типы насаждений как сугубо хозяйственные единицы, А. А. Крюденер подошел к их выделению с широких теоретических позиций. Еще до выхода в свет известной статьи Г.Ф. Морозова о типах насаждений (Morozov, 1904), А.А. Крюденер определил их как «сумму всех факторов, дающих понятие об известном лесе, в том числе климат, почвы, инсоляцию, определяющие состав насаждений, условия возобновления и характер ведения лесного хозяйства» (Krüdener, 1903, p. 1440], что свидетельствовало о понимании им типа насаждения как лесной экосистемы. Позже он даст удивительно четкое как по смыслу, так и по форме классическое определение типа насаждения как экосистемы, выделив три фактора - климат, почвогрунт и растительное сообщество, - «которые, будучи связаны вместе, дают нам понятие о типе насаждения〉 [7, с. 23]. К сожалению, термина, определяющего в целом это единство живой и косной компонент природы, подобного экосистеме Tansley (1935) Крюденер не предложил, отнеся тип насаждения, как и Морозов, к географическому понятию - элементарному ландшафту (Krüdener, 1926).

В 1901 г. А.А. Крюденер вступил в Петербургское отделение Лесного общества и в течение многих лет был одним из наиболее активных его членов. Он часто выступал на заседаниях общества, нередко читая доклады, богато иллюстрированные таблицами, фотографиями, гербарием, перед огромной по тем временам аудиторией - до 130-150 человек, тогда как обычно на заседаниях общества присутствовало 20-30 человек.

Основное внимание в своих исследованиях А. А. Крюденер сосредоточил на изучении влияния почвенно-грунтовых условий на состав и продуктивность лесов. В его первой публикации (Krüdener, $1903)$ дана бонитировка лесных почв с выделением их классов по отношению к росту сосны в зависимости от условий увлажнения, и приведены списки растений напочвенного покрова, характерных для этих классов, - сухих, свежих, влажных, сырых и болотистых. По убеждению автора, эти растения 
весьма достоверно отражают плодородие почв, их физические свойства и влажность.

Наиболее злободневным вопросом нового учения о типах насаждений была разработка их классификации. Решения этого вопроса ждали от Г. Ф. Морозова. Будучи приверженцем идей В.В. Докучаева, Г.Ф. Морозов попытался положить в основу классификации типов насаждений генетические типы почв (Morozov, 1913). Однако эта попытка успехом не увенчалась. А. А. Крюденер в вопросах классификации лесов пошел другим путем - путем обобщения многовекового опыта сельского и лесного населения России, издавна разделявшего леса в зависимости от их состава и местоположения на ряд типов и давшего этим типам весьма образные названия - боры, рамени, дубравы, ольсы и др. В течение 25 лет он по крупицам собирал эти знания в разных районах России. Многие русские лесоустроители высоко ценили народные лесоводственные знания и термины, но только А. А. Крюденеру удалось наиболее полно обобщить народный опыт и создать на его основе единую классификацию лесов Европейской России, опубликованную им в монографии «Основы классификации типов насаждений и их народнохозяйственное значение в обиходе cmpaны»». Два ее тома вышли в выпусках «Материалов по изучению русского леса» (19161917), являвшихся бесплатным приложением к «Лесному журналу», редактировавшемуся в те годы Г.Ф. Морозовым. Третий том, который должен был содержать описания наиболее богатых типов леса (раменей, дубрав), к сожалению, не увидел света. В 1918 г. А. А. Крюденер был вынужден эмигрировать. Сначала он с семьей выехал в Финляндию, оттуда в Швецию, затем в Германию.

Трудно сложилась жизнь ученого за границей. В течение нескольких лет он в качестве лесного рабочего, а затем мастера-взрывника корчевал пни в лесах, вырубленных в период Первой Мировой войны, занимался другими временными работами. Знание нескольких иностранных языков позволило ему заняться реферированием научных журналов (1923-1926 гг.). Лишь спустя 10 лет, в 1928 г., он получил место специалиста-почвоведа, а позже советника по благоустройству улиц и инженернобиологическим вопросам.

Многие годы А.А. Крюденер пытался продолжить в Германии работы лесотипологического плана, начатые в России. Ему удалось переиздать там сокращенный вариант своей монографии (Krüdener, 1927) и опубликовать ряд статей, в которых он излагал основы своей классификации с использованием русских народных названий типов леса. В одной из его первых статей, опубликованных в Германии, дан развернутый анализ природоведческих знаний «людей природы», жителей северных лесных районов России, обладавших значительным объемом сведений о своем климате, почвах, растительности и глубоко понимавших существующие между ними взаимосвязи. Мы переиздали эту часть работы (Krüdener, 2008).
Однако русская типологическая классификация не получила распространения в Западной Европе, где леса сильно изменены человеком. Тем не менее, ряд более поздних работ А.А. Крюденера, касающихся выявленных им значительных потерь прироста древесины в связи с неполным использованием ресурсов их местообитаний чистыми культурами ели, способствовал формированию у немецких лесоводов представлений о местообитании как основе практического лесоводства. Он создал также Лесной отдел в Мюнхенском природоведческом музее, к сожалению, уничтоженный в годы войны. На его центральной экспозиции была размещена серия типов леса в виде экологического ряда от низкобонитетных сосняков к сложным смешанным высокопродуктивным насаждениям, а далее - к низкобонитетным чистым ельникам, с почвенными монолитами разных типов. Ранее в Петербурге он также создал Музей леса. В нем были представлены монолиты почв разных типов леса, гербарий лесных растений, сотни фотографий, в том числе цветных.

В последующие годы, в связи со спецификой своей трудовой деятельности, А.А. Крюденер занялся исследованиями на стыке биологии и инженерии, вопросами применения биологических и лесохозяйственных методов при закреплении оврагов и откосов, строительстве дорог, водохранилищ и др. В Германии он считается родоначальником новой научной отрасли - инженерной биологии, с помощью которой решаются проблемы охраны природы в союзе с техникой. Его монография «Engineering Biologie» (Инженерная биология) вышла в свет в год смерти автора - в 1951 году. Всего же в Германии А.А. Крюденер опубликовал более 150 работ, в т.ч. 60 типологических очерков и 10 монографий. Среди последних, два тома воспоминаний о России с поэтическим названием «Unendliche Weiten» (Бескрайние просторы). Присланный нам родными А.А. Крюденера список его трудов, опубликованных в Германии, приведен в статье М.Д. Мерзленка (Merzlenko, 2001). Следует заметить, что все эти работы написаны А. А. Крюденером в возрасте более 60 лет. Лесной институт в Эберсвальде присвоил ему звание почетного доктора. Однако, работая без отдыха до глубокой старости, ученый так и не смог получить пенсии. Скончался А. А. Крюденер 5 ноября 1951 г. в Мюнхене.

В ряде журналов, в том числе в Международном лесном журнале, были помещены некрологи, написанные видными немецкими лесоводами. Из некролога К. Рубнера (1952) мы почерпнули большую часть сведений о жизни А. А. Крюденера, поскольку автор пользовался его автобиографическим очерком. Из этого очерка, так же как и из публикаций самого А. А. Крюденера, следует, что он до последних дней оставался экологом в русском, морозовском значении этого слова. Он всегда подчеркивал, что родился и в течение четверти века работал в России, которую изъездил «от тундры у Ледови- 
того океана и девственных лесов Севера до степей Туркестана и снежных вершин Кавказских гор». Его родные сообщили нам, что А.А. Крюденер всегда чувствовал себя связанным с Россией, служению которой он отдал лучшие годы своей жизни. В России же был создан главный его труд «Ocнoвbl классификации типов насаждений», в котором он предложил первую в истории науки сопряженную классификацию лесов и почвогрунтов, классификаизию лесных экосистем.

А.А. Крюденер начал разрабатывать типологическую классификацию лесов, ломая все утвердившиеся в научном познании классификационные каноны. В естественных науках с начала их развития утвердился выдвинутый Э. Кантом и поддержанный другими философами принцип, по которому классификация объектов разных наук должна основываться на свойствах самих этих объектов, на их так называемых «внутренних» свойствах. Этот краеугольный классификационный прием, вполне естественный и законный при систематизации автономных объектов, настолько прочно укоренился, что трудно представить, какие причины могли бы побудить профессионального ученого его нарушить. Однако в естественных науках этот прием практически полностью закрывает или во всяком случае крайне затрудняет возможности выявления существующих между разными природными факторами многообразных взаимосвязей, познание единства природы. В противоположность издавна идущей и все усиливающейся дифференциации, дробления и специализации естественных наук, в народе сформировалось и утвердилось синтетическое восприятие природы в единстве и тесной соподчиненности всех слагающих ее компонентов. Эти народные представления для А.А. Крюденера, на протяжении многих лет собиравшего их так, как собирают сказания, былины, явились основой, на которой он создал свою классификацию.

Так же, как и Г. Ф. Морозов, А. А. Крюденер отводил определяющую роль в формировании типов насаждений внутри однородных в климатическом отношении территорий почвенно-грунтовым условиям. Характеристика почвогрунтов и почвенногрунтовых условий (А.А. Крюденер разделял эти два понятия, последнее шире, с учетом особенностей рельефа и условий увлажнения) дается им на основе всех последних достижений молодой тогда науки - генетического почвоведения. В то же время описания А.А. Крюденера очень самобытны, поскольку во главу угла им ставилась не собственно почва как таковая, а почва как субстрат, как среда произрастания растений.

В процессе предпринятого ученым массового изучения почв разных типов леса, которое он вел на протяжении многих лет, была выявлена тесная связь характера лесной растительности не с генетическими типами почв, а с их плодородием, с их лесорастительным потенцииалом. Уже в своей первой публикации (Krüdener, 1903) ученый очень убедительно показал значение условий увлажнения для роста сосновых насаждений, определяющих их бонитет, их продуктивность. При этом он выделил ряд видов растений, позволяющих оценивать уровень обеспеченности почв влагой (от сухих до заболоченных), предприняв новый прием оценки качества почв - метод фитоиндикации. Позже им была установлена связь характера лесов с обеспеченностью почвогрунтов питательными веществами, обусловливающая, вследствие разной требовательности к ним древесных пород, разный состав насаждений.

Оценивая качество почв как поставщика элементов питания, ученый так же, как издревле землепашцы, ставит на первое место механический, точнее петрографический (породный) состав грунтов, из которых они образовались, поскольку существует тесная связь между механическим и минералогическим составом пород, а, следовательно, и их химическим составом: с утяжелением механического состава в них возрастает содержание всех элементов питания растений, отсутствующих в крупных песчаных фракциях. Эта связь очень жестко прослеживается повсеместно, в разных регионах, хотя она не абсолютна, и среди наиболее потенциально плодородных А. А. Крюденер выделил породы разного механического состава, богатые фосфором и калием, - силурийские известняки, юрские глауконитовые пески, девонские глинь.

Характеризуя условия водообеспеченности, которым А.А. Крюденер отводил определяющую роль в жизни леса, он прежде всего учитывал положение в рельефе и степень дренированности территорий, глубину залегания и режим подвижности (проточности) грунтовых вод. Хорошим показателем условий увлажнения и питания насаждений на разных почвогрунтах ученый считал характер верхнего гумусового горизонта почв - мощность лесной подстилки, степень разложенности органического вещества, тип гумуса (кислый, нейтральный, сладкий) или торфа. На использовании этих показателей, a, именно, петрографического состава почвогрунтов, определяющего содержание в них элементов питания и хорошо отражаемого механическим составом, положения в рельефе, степени дренированности (глубины залегания и режима грунтовых вод), характера верхнего гумусового горизонта и создает А. А. Крюденер свою классификацию почвогрунтов, подразделяя их на типы не по строению профиля, по которому определяются их генетические типь, а по различиям состава и продуктивности произрастающих на них насаждений. Растительность, принята Крюденером как критерий качества почв, причем обязательно не только ее состав, но и продуктивность. Заметим, что лесоводы морозовского периода чаще использовали термин «почвогрунты», а не «почвы» не только потому, что древесные растения имеют заглубленные корневые системы, но и потому, что хорошо понимали, какое большое значение для почв имеют породы, из которых они сформировались. 
Для типов почвогрунтов и лесов на них ученый сохранил народные названия (бор, суборь, рамень, согра и др.), которыми широко пользовались типологи морозовского периода. Но в его классификации эти типы размещены в строгой системе - no нарастанию богатства и увлажнения субстрата. Так появился координатный принцип оценки качества почвогрунтов по двум главным составляющим их плодородия - обеспеченности элементами питания и влагой, - ставший основой характеристики местообитаний во всех последующих классификационных построениях лесных типологов морозовской школы. Принцип обязательного одновременного учета двух факторов плодородия пищи и влаги - настойчиво пропагандировали П. А. Костычев и В. Р. Вильямс. Обратим внимание на тот факт, что координатный принцип классификации А. А. Крюденер воспринял от Н. М. Сибирцева, создавшего классификацию почв в координатах их генетических типов и петрографических групп (от глин до песков) (Sibirtsev, 1951).

Классификационная таблица А.А. Крюденера состоит из двух частей. В верхней части (A) выделены три больших группы земель, существенно различающихся по степени и режиму увлажнения, а именно: суходолы, поймы и заболоченные земли. В этой же части, в зависимости от условий увлажнения и дренажа, указаны типы почв по характеру их гумусированности (нейтральный, кислый перегной, торф). В нижней части (В) дано деление почвогрунтов (субстратов) по петрографическому составу и степени увлажнения. Придавая определяющую роль влаге, Крюденер выделил 15 групп почвогрунтов по их влажности (степени увлажнения и характеру дренажа), в том числе 5 суходольных, 3 пойменных, 7 разной степени заболоченности. По петрографическому составу субстратов выделено 7 групп: 3 одноярусных (пески, супеси и суглинки) и 4 двухъярусных, двучленных (пески, подстилаемые суглинками и др.). Фрагмент этой части классификации приведен в таблице. Он прекрасно раскрывает главный ее принцип: рассматривая растительность как «отражение» субстрата, А. А. Крюденер разделяет почвогрунты на типы не по их особенностям, не по их «внутренним» свойствам, а по приуроченности к ним разных типов насаждений, состав и продуктивность которых обусловлены тем или другим уровнем их плодородия.

Особенно глубоко, как нам представляется (как никем ни до, ни после А.А. Крюденера), охарактеризованы в этом отношении почвогрунты. Здесь и значение почвенного климата, и закон минимума питательных солей и допустимого максимума вредных веществ, и характер круговорота веществ в процессе жизнедеятельности растительности и токов влаги, и роль тления, гниения и других микробиологических процессов в «кипучей» жизни почв. В данном случае безусловно имел значение тот факт, что в Лесном институте А.А. Крюденер слушал лекции П.А. Костычева, рассматривавшего почвы прежде всего как среду обитания растений. Очень оригинально данное А.А. Крюденером определение производительности почв - потенциальной, как богатых элементами питания, но недостаточно обеспеченных водой и воздухом, и актуальной, при наиболее гармоничном сочетании воды и воздуха. Серьезное внимание уделено вопросам бережного отношения к природе («лесовод не хищник, девиз которого “после меня хоть потоп"»), в том числе необходимости учета разной устойчивости почвогрунтов, в частности «хрупкости» песчаных массивов, и значения болот как накопителей влаги и нецелесообразности в связи с этим их широкого осушения.

Очень большую ценность представляет лесохозяйственный аспект монографии, второй ее книги, изданной в 1917 году. Автор детально охарактеризовал в ней древостои разных типов и их вариации в зависимости от рубок, пожаров, выпаса скота, нападения вредителей. Даны подробные таксационные описания типичных типов насаждений в разных зонах и областях. Практическая направленность работы проявляется при анализе смен пород под влиянием рубок и стихийных факторов. Даются дифференцированные рекомендации по проведению рубок в разных типах леса с тем, чтобы повысить надежность естественного возобновления. Для каждого типа леса указаны его примерная стоимость для налогового обложения и пути наиболее рационального использования, в том числе в плане сельскохозяйственного освоения - под пашни, сенокосы, выпасы.

Классификационное построение А.А. Крюденера представляет первый опыт сопряженной классификации лесов и их местообитаний, лесов и лесообразователей - климата (классификации почвогрунтов предпослано первое лесорастительное районирование Европейской России, разработанное А.А. Крюденером) и почвогрунтов, - создающих в природе сложные единства, получившие позже название экосистем (см. табл.). Это совершенно новый тип классификации, основной принцип которого - классификация лесов по факторам среды, их формирующих, - почерпнут в народной среде («каков грунт земли, таков $u$ лес»). Выделение ведущих признаков почвогрунтов - состава субстрата и уровня увлажнения, положенных в основу классификации, и принцип ее построения - система координат - позволили привести в строгую систему все разнообразие насаждений лесной зоны - от чисто сосновых древостоев на бедных песчаных землях (боры) до раменей и дубрав (грудов) на богатых суглинках. Эти крупные обобщения явились результатом того, что А.А. Крюденеру удалось очень умело объединить многовековой народный опыт с новейшими достижениями лесоводства и почвоведения.

Заканчивая анализ исследования А.А. Крюденера подчеркнем, что он предложил первую экологическую классификацию лесов Европейской России по принципу районирования ее территории по основным климатическим показателям, с последующим разделением лесов в пределах 
климатических зон и областей на типы насаждений по особенностям петрографического состава и водного режима почвогрунтов. Леса на породах одного минерального состава (например,боры на кварцевых песках) в разных зонах выделены им как географические формы одного типа. Это одно из наиболее крупных научных достижений ученого, первым показавшим, что в разных природных зонах на близких по потенциальному плодородию поверхностных отложениях формируются аналогичные местообитания (почвогрунты) и аналогичные типы растительных сообществ. На этом основании А. А. Крюденер отнес зональные типы тайги и лесостепи - рамени (сложные ельники) и дубравы - к одному типу, чего в свое время не смог воспринять даже Г.Ф. Морозов. Будучи руководителем Лесного отдела Управления уделов, в ведении которого находилось более 7 млн га лучших лесных массивов России, и проводя большие работы по их лесоустройству, А.А. Крюденер способствовал тому, что его классификация начала быстро внедряться в производство. Заметим, что экологическая сущность классификационных построений А.А. Крюденера никогда ни кем не отмечалась. Более того, В.Н. Сукачев жестко критиковал этот классификационный прием за то, что он основывается не на признаках, присущих растительным сообществам, а на внешних по отношению к ним.

Однако бурный морозовский этап развития лесной типологии, во время которого работал А.А. Крюденер, был остановлен 1-ой Империалистической войной и революционными событиями. Когда в середине 1920-х годов начали разворачиваться широкомасштабные работы по инвентаризации лесов СССР и лесоустройству, положение в лесной науке было совсем другим. Г.Ф. Морозов в 1920 г. умер, А. А. Крюденер эмигрировал. Его классификация была изъята из употребления и заменена ботанической, точнее фитоценотической (от фитоценоз - растительное сообщество) классификацией Каяндера-Сукачева, не опирающейся на среду и почвогрунты (Cajander, 1909, Sukachev, 1972), как классификации Г. Ф. Морозова и А.А. Крюденера. Ряд крупных лесничих в знак протеста подали тогда прошения об отставке.

Таблица

Главные типы почвогрунтов и типичные почвенно-грунтовые условия в зависимости от увлажнения, доступа воздуха и характера верхнего слоя растительной почвы, дающие при наличности известного древостоя определенные типы насаждений (Krüdener, 1926) (с сокращениями)

\begin{tabular}{|c|c|c|c|c|c|c|}
\hline \multirow{5}{*}{$\begin{array}{c}\text { Петрографическая } \\
\text { группа } \\
\text { (субстрат) }\end{array}$} & \multicolumn{6}{|c|}{ Гигрометрическая группа } \\
\hline & \multicolumn{5}{|c|}{ I } & II \\
\hline & \multicolumn{5}{|c|}{ Суходольные типы надлуговых террас } & \multirow{2}{*}{$\begin{array}{c}\text { Припойменный } \\
\text { тип }\end{array}$} \\
\hline & \multicolumn{5}{|c|}{ По минеральному субстрату разных степеней опозоленности } & \\
\hline & 1 & 2 & 3 & 4 & 5 & 6 \\
\hline $\begin{array}{l}\text { Одноярусные: } \\
\text { Песчаные Боры }\end{array}$ & $\begin{array}{c}\text { Сухой } \\
\text { бор }\end{array}$ & $\begin{array}{c}\text { Свежий } \\
\text { наземистый бор }\end{array}$ & $\begin{array}{c}\text { Свежий } \\
\text { бор кисло- } \\
\text { перегнойный }\end{array}$ & $\begin{array}{c}\text { Влажный } \\
\text { бор кисло- } \\
\text { перегнойный }\end{array}$ & $\begin{array}{c}\text { Влажный } \\
\text { наземистый } \\
\text { бор }\end{array}$ & $\begin{array}{l}\text { Илистый } \\
\text { бор }\end{array}$ \\
\hline $\begin{array}{l}\text { Супесчаные } \\
\text { Субори }\end{array}$ & & $\begin{array}{c}\text { Свежая } \\
\text { наземистая } \\
\text { суборь (грудовая) }\end{array}$ & $\begin{array}{l}\text { Свежая } \\
\text { суборь }\end{array}$ & $\begin{array}{c}\text { Влажная } \\
\text { суборь }\end{array}$ & $\begin{array}{c}\text { Влажная } \\
\text { наземистая } \\
\text { суборь (грудовая) }\end{array}$ & $\begin{array}{l}\text { Илистая } \\
\text { суборь }\end{array}$ \\
\hline $\begin{array}{l}\text { Суглинистые } \\
\text { Рамени }\end{array}$ & & $\begin{array}{c}\text { Свежая } \\
\text { наземистая } \\
\text { рамень (груд) }\end{array}$ & $\begin{array}{l}\text { Свежая } \\
\text { рамень }\end{array}$ & $\begin{array}{c}\text { Влажная } \\
\text { рамень }\end{array}$ & $\begin{array}{c}\text { Влажная } \\
\text { наземистая рамень } \\
\text { (низкий груд) }\end{array}$ & $\begin{array}{c}\text { Илистая } \\
\text { рамень } \\
\text { (грудовый олес) }\end{array}$ \\
\hline $\begin{array}{l}\text { Двухъярусные: } \\
\text { сурамени }\end{array}$ & & $\begin{array}{c}\text { Свежая } \\
\text { наземистая } \\
\text { сурамень }\end{array}$ & $\begin{array}{c}\text { Свежая } \\
\text { сурамень }\end{array}$ & $\begin{array}{l}\text { Влажная } \\
\text { сурамень }\end{array}$ & $\begin{array}{c}\text { Влажная } \\
\text { наземистая } \\
\text { сурамень }\end{array}$ & $\begin{array}{l}\text { Илистая } \\
\text { сурамень }\end{array}$ \\
\hline $\begin{array}{l}\text { Мелкие боры, } \\
\text { субори }\end{array}$ & & См. выше & См. выше & См. выше & См. выше & См. выше \\
\hline $\begin{array}{l}\text { Мелкие рамени } \\
\text { на каменном } \\
\text { субстрате }\end{array}$ & & См. выше & См. выше & См. выше & См. выше & См. выше \\
\hline $\begin{array}{l}\text { Мелкая рамень } \\
\text { на песчанистом } \\
\text { субстрате }\end{array}$ & & См. выше & См. выше & См. выше & См. выше & См. выше \\
\hline
\end{tabular}


Продолж. табл.

\begin{tabular}{|c|c|c|c|c|c|c|c|c|c|c|}
\hline \multirow{4}{*}{$\begin{array}{c}\text { Петрографи- } \\
\text { ческая группа } \\
\text { (субсстрат) }\end{array}$} & \multicolumn{10}{|c|}{ Гигрометрическая группа } \\
\hline & \multicolumn{3}{|c|}{ II } & \multicolumn{7}{|c|}{ III } \\
\hline & \multicolumn{3}{|c|}{$\begin{array}{c}\text { Припойменный } \\
\text { тип }\end{array}$} & \multicolumn{7}{|c|}{ Типы, как результат постепенного заболачивания } \\
\hline & & 7 & 8 & 9 & 10 & 11 & 12 & 13 & 14 & 15 \\
\hline $\begin{array}{l}\text { Одноярусные: } \\
\text { Песчаные Боры }\end{array}$ & \multirow{4}{*}{$\stackrel{\tilde{s}}{\circ}$} & \multirow{4}{*}{ 蛋 } & \multirow{4}{*}{ 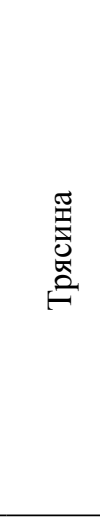 } & Подборье & & & & & $\begin{array}{c}\text { Бор надбо- } \\
\text { лотный }\end{array}$ & $\begin{array}{c}\text { Сырой } \\
\text { бор }\end{array}$ \\
\hline $\begin{array}{l}\text { Супесчаные } \\
\text { Субори }\end{array}$ & & & & -"- & & & & & $\begin{array}{c}\text { Суборь } \\
\text { надболотная }\end{array}$ & $\begin{array}{l}\text { Сырая } \\
\text { суборь }\end{array}$ \\
\hline $\begin{array}{l}\text { Суглинистые } \\
\text { Рамени }\end{array}$ & & & & $\begin{array}{l}\text { Подра- } \\
\text { менье }\end{array}$ & \multicolumn{3}{|c|}{ Согра } & & $\begin{array}{l}\text { Рамень } \\
\text { надбо- } \\
\text { лотная }\end{array}$ & $\begin{array}{l}\text { Сырая } \\
\text { рамень }\end{array}$ \\
\hline $\begin{array}{l}\text { Двухъярусные: } \\
\text { сурамени }\end{array}$ & & & & $-"-$ & $\begin{array}{c}\text { Пендус } \\
\text { (боровой, } \\
\text { раменный) }\end{array}$ & & $\begin{array}{l}\text { Сумшара } \\
\text { (боровая, } \\
\text { раменная) }\end{array}$ & $\begin{array}{c}\text { Мшара } \\
\text { (боровая, } \\
\text { раменная) }\end{array}$ & $\begin{array}{c}\text { Сурамень } \\
\text { надбо- } \\
\text { лотная }\end{array}$ & $\begin{array}{l}\text { Сырая } \\
\text { сурамень }\end{array}$ \\
\hline $\begin{array}{l}\text { Мелкие боры, } \\
\text { субори }\end{array}$ & $\begin{array}{l}\text { См. } \\
\text { выше }\end{array}$ & $\begin{array}{l}\text { См. } \\
\text { выше }\end{array}$ & $\begin{array}{l}\text { См. } \\
\text { выше }\end{array}$ & $\begin{array}{l}\text { См. } \\
\text { выше }\end{array}$ & & & & & См. выше & $\begin{array}{c}\text { См. } \\
\text { выше }\end{array}$ \\
\hline $\begin{array}{l}\text { Мелкие рамени } \\
\text { на каменном } \\
\text { субстрате }\end{array}$ & -" & $-"-$ & $-"$ & $-"$ & & & & & $-"$ & -"- \\
\hline $\begin{array}{l}\text { Мелкая рамень } \\
\text { на песчанистом } \\
\text { субстрате }\end{array}$ & $-"-$ & $-"-$ & $-"-$ & $-"$ & & & & & $-"$ & $-"-$ \\
\hline
\end{tabular}

Благодаря усилиям Г.Н. Высоцкого, классификация А.А. Крюденера сохранилась в Украине как классификация Е.В. Алексеева, использовавшего разработки А.А. Крюденера после переезда из Петербурга в Киев и создавшего на их основе сокращенный вариант его классификации применительно к украинским лесам (Alekseev, 1925). Ученик Г.Н. Высоцкого П.С. Погребняк, продолжая подходы Е.В. Алексеева, в процессе работ организованной Г.Н. Высоцким исследовательской партии, преобразовал центральный фрагмент таблицы А.А. Крюденера в очень удобную компактную классификационную модель в координатах четырех типов богатства (трофности) и шести типов увлажнения земель (Pogrebnyak, 1931, Pogrebnyak, 1955), получившую название эдафической сетки (от edaphos - почва, земля). При этом он объединил типы леса А.А. Крюденера на карбонатных и кислых породах (наземистые и кислоперегнойные), выделив их на уровне вариантов (кальциефильные и ацидофильные). С этого началось формирование украинской школы лесной типологии. Идеи А.А. Крюденера оказали влияние на воззрения известного геоботаника Л. Г. Раменского (Ramensky, 1938, Ramensky et al., 1956). Однако в целом научное наследие А. А. Крюденера не получило того широкого признания и применения, которого оно заслуживает.
Монография А.А. Крюденера, опубликованная в период первой мировой войны накануне больших революционных событий и эмиграция ее автора обусловили тот факт, что она осталась почти неизвестной и не была по достоинству оценена ни у нас, ни за рубежом. Между тем, теоретические разработки А.А. Крюденера, созданные в России, являются выдающимся вкладом не только в лесоводство, но и в естествознание в целом. Его сопряженная классификация лесов и основных факторовлесообразователей - климата и почвогрунтов - представляет высшую форму классификации, классификацию сложных природных объектов, природных систем. Ведущим фактором в этой классификации выступает абиотическая среда, но подразделение ее на типы произведено не по ее «внутренним» свойствам, как это общепринято, а по произрастающей растительности, которая признается главным критерием качества условий среды. Именно этот прием превращает классификацию А.А. Крюденера в классификацию экосистем, биогеоценозов.

Использование растительности для оценки условий среды в течение всей жизни оставалось постоянной и возможно самой большой научной привязанностью А.А. Крюденера. Он по праву может быть назван одним из зачинателей индикационной геоботаники. В Германии им были изданы специальная монография $(1933,1949)$ и большой атлас 
растений-индикаторов (Krüdener, Becker, 1941). На фитоиндикации базируются и разработки его инженерной биологии.

А.А. Крюденер не был профессиональным ученым, он был прежде всего лесоводомпроизводственником, таксатором, лесоустроителем. Поэтому над ним не довлели классификационные догмы естественных наук и ему оказалась совершенно чуждой та фитосоциальная шумиха, против которой не смог устоять даже Г.Ф. Морозов. А.А. Крюденер всегда оставался верным экологическим принципам. Такого счастливого сочетания качеств могло больше не повториться. А потому и классификация экосистем еще долгие годы не была бы создана. Тем более, что народные знания о природе к настоящему времени в значительной мере утрачены, а естественная растительность, наиболее адекватно отражающая природную среду, почти не сохранилась. Во всяком случае последователи А.А. Крюденера - П.С. Погребняк и Л.Г. Раменский всеми этими данными не располагали. И вряд ли они состоялись бы как столь крупные ученые, не будь основополагающего задела, созданного А.А. Крюденером. То, что они мало ссылались на его труды, вполне объяснимо - имя А. А. Крюденера было в те годы под запретом.

Весьма интересна последняя работа ученого «Инженерная биология», основной идеей которой является доказательство необходимости единения технических наук и биологии, познания инженерами законов живой природы. А. А. Крюденер убедительно раскрывает важность при проведении всех инженерно-технических работ в полевых условиях учета характера природных ландшафтов, их биологической компоненты, с тем чтобы не только не вызвать возникновения серьезных негативных последствий, но, наоборот, постараться повысить их производительные возможности и при этом сохранить красоту природы, «которая никогда не бывает в тягость, а наоборот снижает подавленность и улучшает настроение». Автор подчеркивает, что природа представляет нерасторжимое единство всех ее компонентов, из которого нельзя выделить отдельные звенья, не повредив целого, не нарушив ее гармонии, ее равновесия. Поэтому все технические изыскания должны быть пронизаны биологическим мышлением. «Природа разговаривает с нами без слов, но ее язык выразителен и красноречив. Мы должны всегда и везде, где это только возможно, учиться его понимать и делать практические выводы» (Krüdener, 1951, p. 65).

Обратим внимание на тот момент, что если в своих разработках проблем лесной типологии А.А. Крюденер первым дал определение и классификацию экосистем (его определение экосистемы как единства климата, почворунтов и растительности гораздо четче, чем у Тэнсли, который только высказал положение о том, что существование растительности без среды невозможно, и дано на 20 лет раньше), то созданная им инженерная биология является безусловно пионерным направлением новой экологии как на- уки о среде и ее охране, промышленной экологии, столь стремительно развивающейся в наше время. К сожалению, ни в том, ни в другом случае приоритет за ученым не закрепился.

Хотя в Германии он смог спустя много лет заняться научной деятельностью, причем, несмотря на преклонный возраст, довольно интенсивной, однако он никогда не имел там таких условий жизни и работы, какие были у него в России. И он всегда помнил и любил ее. Ни революция, ни сталинские репрессии, ни германский фашизм не смогли убить эту его любовь. До конца жизни с ним оставались и «прекрасная» Волга, и «великий» Пушкин, и в целом родные ему русская природа и русский народ. Свидетельством тому являются его необыкновенно одухотворенные поэтические воспоминания «Необозримые просторы» (Krüdener, 2001), переизданные, также как и его монографии «Инженерная биология» и «Основы классификации...», благодаря поддержки профессоров М.Д. Мерзленка и В. Д. Никишова в 2001-2003 гг., МГУЛ'ом.

Наиболее важным результатом деятельности А.А. Крюденера является формирование украинской школы лесной типологии, которая уже многие годы служит в Украине теоретической основой научного лесоводства и лесохозяйственного производства (Pogrebnyak, 1931, 1955, Vorobiev, 1953, Lavrynenko, 1954, Belgard, 1971, Tkach, 1999, Ostapenko, \& Tkach, 2002, Migunova, 2007, 2014). Поскольку изначально имя барона-эмигранта А.А. Крюденера в работах украинских типологов не называлось, со временем и сами типологии привыкли считать их результатом исследований представителей украинской школы лесной типологии. Когда в 1980 г. мы познакомились с монографией А.А. Крюденера 1916 г., нам пришлось потратить немало усилий на то, чтобы восстановить его приоритетную роль в создании украинских разработок и собрать в Германии с помощью немецких лесоводов его биографические и другие данные. В России, где он учился и работал, в то время о нем уже ничего не было известно.

Основные достижения украинской школы - создание на основе центрального фрагмента классификационной таблицы А.А. Крюденера учеником Г.Н. Высоцкого П.С. Погребняком весьма совершенной классификационной модели - эдафической сетки, систематизирующей в координатах четырех типов богатства (трофности) и шести типов увлажнения (плюс их вариации) все разнообразие лесов разных природных зон. Вторым крупным достижением украинских типологов является обоснование использования метода фитоиндикации как основного при оценке плодородия почв. Первые типологи определяющее значение придавали изучению почв. Это однако никак не отрицает необходимости изучения почв разных типов леса. Очень важным фактом является создание климатических сеток, подобных эдафической, что позволяет характеризовать зональное и внутризональное разнообразие не только лесов, но и природы в целом (Migunova, 
2014). А.А. Крюденер учитывал климат, предложив первое лесорастительное районирование России. Им разработана система лесотипологических таксонов, дано их количественное обоснование. Безусловно украинские типологи внесли весьма существенный вклад в методы изучения и само изучение типологического разнообразия лесов, в том числе очень сложных в природном отношении лесов ряда горных систем (Карпаты, Крым, Кавказ). Очень большой объем работ проведен по внедрению разработок лесной типологии в лесохозяйственное производство. Мы не говорим уже о том, что украинские лесоводы спасли от полного забвения предложенный А.А. Крюденером приниип экологической классификачии лесов по обусловленности их состава и продуктивности плодородием среды - плодородием климата и почвогрунтов.

Классификационные построения и ряд теоретических разработок украинской школы требуют доработки и совершенствования. Это касается прежде всего более четкого разграничения зонального и внутризонального разнообразия типов леса. До сих пор нет твердо установленного понимания того, что основная классификационная модель лесной типологии - эдафическая сетка - классифицирует разнообразие лесов в пределах однородного климата, ею не учитываются различия климатических особенностей, прежде всего обеспеченность теплом.

Климат оказывает огромное влияние на растительность, определяя ее главную особенность - зональность. Поэтому любая работа в лесу предполагает прежде всего установление зоны, в горах высотного пояса, в которых объект находится. Типологическое разнообразие лесов обусловлено особенностями состава и строения поверхностных отложений, являющихся почвообразующими породами, внутри зон. Эдафическая сетка систематизирует древесные породы по их требовательности к пище и влаге, климатические - по теплолюбию и морозоустойчивости.

А.А. Крюденер начал разработку своей классификации с лесорастительного районирования России - выделения территорий, однородных по климату. Сама классификация основана на результатах изучения лесов таежной зоны европейской части России. Объединение одинаковых по составу типов леса трех зон равнинной Украины (Полесья, Лесостепи и Степи), как это сделал Б. Ф. Остапенко при составлении кадастра типов леса (Migunova, 2014), вследствие чего сухие боры Полесья и Степи оказались в одном типе, неправомерно. Нужно пользоваться кадастрами типов леса отдельных зон. Целесообразно также разделение Степи на две зоны - Степь и Сухая степь (южные черноземы и темно-каштановые почвы). В лесорастительном отношении эти две зоны различаются больше, чем типичная Степь и Лесостепь. В весьма совершенном лесорастительном районировании Украины Lavrynenko (1954) выделил Южную степь, аналогичную нашей Сухой.
Необходимо обратить больше внимания на различия карбонатности местообитаний. А. А. Крюденер относил леса на карбонатных и кислых породах к разным типам - наземистым и кислоперегнойным. П. С. Погребняк выделил их на уровне вариантов кальциефильных и ацидифильных. В последних кадастрах типов леса Украины этого деления нет. Примером кальциефильных (карбонатных) вариантов являются леса с участием ясеня обыкновенного (ясенево-липовые дубравы). Ацидифильными вариантами являются леса из пихты белой в зоне буковых лесов Карпат. Эти факты должны обязательно учитываться в лесокультурном деле при подборе пород.

В целом, широколиственные породы тяготеют к карбонатным почвогрунтам, хвойные - к кислым. Но даже главная порода таежных лесов - ель - на карбонатных породах отличается значительно более высокой продуктивностью, чем на кислых. Совершенствования требуют определения типов леса их четырех основных групп - боров, суборей, сугрудов и грудов (дубрав, бучин, раменей, пихтачей, ольсов) и их объединение в хозяйственные группы. А далее - разработка системы ведения лесного хозяйства на зонально-типологической основе.

Выводы. А. А. Крюденер создал классификацию типов насаждений, положив в ее основу плодородие почвогрунтов. Плодородие, способность воспроизводить растения, является главным качеством, отличающим почвы от всех других природных тел, представляет их ни с чем не сопоставимую функиию, миссию на Земле, поскольку без растений, осуществляющих процесс фотосинтеза, переводящего неорганические соединения в органические, жизнь невозможна. Когда типологи вслед за А. А. Крюденером разместили леса по плодородию их местообитаний, природа из живописного хаоса превратилась в строгую и стройную систему, в которой все можно пролонгировать и рассчитать. Суммарным показателем плодородия среды является количество, соотношение и распределение по сезонам года лимитированных экологических ресурсов - тепла, влаги и пищи, впервые определенных как «элементы жизни растений» Г.Н. Высоцким (Vysotsky, 1904). Они определяют все разнообразие природы нашей планеты. Лесотипологические классификационные модели построены в координатах этих ресурсов - климатическая сетка в координатах тепла и атмосферного увлажнения, эдафическая - в координатах пищи и влаги почвогрунтов. Поэтому они применимы не только для классификации лесов, но и природы в целом. Полагаем поэтому, что со временем эти принципы будут приняты во многих естественных науках.

Следует отметить, что основополагающие положения украинской школы лесной типологии восходят к А. А. Крюденеру, его монографии «Основы классификации типов насаждений». Но А. А. Крюденер был еще и крупным таксатором, лесоустроителем. И его вклад в эти разделы лесоводства также требует отдельного анализа и обобщения. 


\section{References}

Alekseev, E.V. (1925). Types of Ukraine's forests. Right bank of the Dnieper river. Kyiv (in Russian).

Belgard, A. L. (1971). Steppe Forestry. Moscow: Forest Industry (in Russian).

Cajander, A. K. (1909). Uber Waldtypen. Acta forestalia fennica

Krüdener, A.A. (1903). The experience of soil cover grouping in relation to site, soil, insolation and renewal under the canopy and on cutting areas. Forest magazine, 6, 1430-1468 (in Russian).

Krüdener A.A. (1908-1913). Volume tables and taper tables of main tree species. Sankt-Petersburg (in Russian).

Krüdener, A. (1926). Waldtypen als kleinste naturliche Landschaftseinhei - ten bzw. Mikrolandschaftstypen. Dr. A. Petermanns Mitteilutrgen aus Justus Peters geograftscher Anstalt, 7-8, 150-158 (in German).

Krüdener, A(1927). Waldtypen. Klassifikation und ihre volkswirtschaftliche Bedeutung. Germany: Verlag Neuman-Neudamm (in German).

Krüdener, A. A. (1951). Biology engineering. Moscow: Moscow State Forest Institute (in Russian).

Krüdener, A. A. (2001). Wide open spaces. 1927, 1937 editions. Moscow: Moscow State Forest Institute (in Russian).

Krüdener, A. A. (2003). Principles of classification of forest stand types and their economic importance in the life of the country. 2nd edition. Moscow: Moscow State Forest Institute (in Russian).

Krüdener, A. A. (2008). Forest typology by people of nature and its significance. 1926. Forestry \& Forest Melioration, 113, 3-7 (in Russian).

Lavrynenko, D. D. (1954). Forest types of the Ukrainian SSR. Moscow: Goslesbumizdat (in Russian).

Merzlenko, M.D. (2001). In memory ofA.A. Kruedener. Forest Herald, 5, 85-92 (in Russian).

Migunova, E. S. (2007). Forestry and natural sciences. 2nd edition. Moscow: Moscow State Forest Institute (in Russian).

Migunova, E.S. (2014). Types of forests and types of nature (environmental relationships). Germany: Palmarium (in Russian).

Morozov, G. F. (1904). About types of forest stands and their significance in forestry. Forest Journal, 1, 6-25 (in Russian).

Morozov, G.F. (1913). Exploration of the forests of the Voronezh province. Forest Journal, 3-4, 463-481 (in Russian).

Ostapenko, B.F., \& Tkach, V.P. (2002). Forest typology. Kharkiv: Kharkiv State Agrarian University (in Ukrainian).

Pogrebnyak, P. S. (1931). Fundamentals of typological classification and methods for making it. Kharkiv (in Ukrainian).

Pogrebnyak, P.S. (1955). Fundamentals of Forest Typology. Kyiv: Academy of Sciences of the USSR (in Russian).
Ramensky, L.G. (1938). Introduction to a comprehensive soil-geobotanical study of land. Moscow-Leningrad: Selkhozgiz (in Russian).

Ramensky, L. G., Tsatsenkin, I.A., Chizhikov, O.N., \& Antipin N.A. (1956). Ecological assessment of forage land by vegetation cover. Moscow: Selkhozgiz (in Russian).

Sibirtsev, N.M. (1951). Soil Science 1900-1901. Selected works. Moscow: Selkhozgiz (in Russian).

Sukachev, V.N. (1972). Fundamentals of forest typology and biogeocoenology. Selected Works. Leningrad: Science (in Russian).

Tansley, A. G. (1935). The use and abuse of vegetation concepts and terms. Ecology, 16 (3), 17-28.

Tkach, V.P. (1999). Floodplain forests of Ukraine. Kharkiv: Right (in Ukrainian).

Vorobiev, D. V. (1953). Types of forests in the European part of the USSR. Kyiv: Academy of Sciences of the USSR (in Russian).

Vysotsky, G.N. (1904). About forest site types map. Modern issues of Russian agriculture, 81-94 (in Russian).

\section{Від створення класифікації лісів як екосистем до формування української школи лісової типології (до 150-річчя від дня народження А. А. Крюденера)}

\author{
В.П. Ткач' , О.С. Мігунова²
}

Поняття лісу як єдності насадження, клімату і грунту, тобто як екосистеми, вперше було визначено А. А. Крюденером. Учений розробив класифікацію лісів за родючістю грунтів, на яких вони ростуть, в координатах їх забезпеченості елементами живлення і вологою. А. А. Крюденер запропонував першу екологічну класифікацію лісів Свропейської Росії за принципом районування іiі території за основними кліматичними показниками, 3 наступним поділом лісів в межах кліматичних зон і областей на типи насаджень за особливостями петрографічного складу і водного режиму грунтів.

\footnotetext{
Ткач Віктор Петрович - академік Лісівничої академії наук України, член-кореспондент НААН України, доктор сільськогосподарських наук, професор, директор. Український науково-дослідний інститут лісового господарства та агролісомеліорації ім. Г.М. Висоцького, вул. Пушкінська, 86, Харків, 61024, Україна. Тел.: (057) 704-10-02. E-mail: Tkach@uriffm.org.ua

Мігунова Олена Сергївна - академік Лісівничої академії наук України, доктор сільськогосподарських наук, професор, головний науковий співробітник. Український науково-дослідний інститут лісового господарства та агролісомеліорації ім. Г.М. Висоцького, м. Харків, Україна. Тел.: (057) 707-80-71. E-mail: migunova-e-s@yandex.ua
} 
Визначальну роль у формуванні типів насаджень усередині однорідних в кліматичному відношенні територій А.А. Крюденер, як і Г.Ф. Морозов, відводив грунтовим умовам, підкреслюючи при цьому, що основним чинником $\epsilon$ не власне грунт як такий, а грунт як субстрат, як середовище виростання рослин. Ученим, в процесі масового вивчення грунтів різних типів лісу, виявлено тісний зв'язок характеру лісової рослинності не 3 генетичними типами грунтів, а 3 їх родючістю, з їх лісорослинним потенціалом.

При цьому для оцінки родючості грунтів А.А. Крюденер використав новий підхід - метод фітоіндикації, тобто критерієм якості грунтів ним прийнята рослинність, іiї склад і продуктивність.

Розробляючи класифікацію лісів, А.А. Крюденер чітко дотримувався координатного принципу оцінки якості грунтів за двома головними складовими їхньої родючості - забезпеченості елементами живлення і вологою, який став визначальним у всіх наступних класифікаційних побудовах лісової типології морозовської школи.

Сумарним показником родючості середовища $є$ кількість, співвідношення і розподіл за сезонами року лімітованих екологічних ресурсів - тепла, вологи і живлення. Лісотипологічні класифікаційні моделі побудовані в координатах цих ресурсів - кліматична сітка в координатах тепла i атмосферного зволоження, едафічна - в координатах живлення і вологи грунтів. Тому вони можуть бути застосовані не лише для класифікації лісів, але й природи загалом.

У статті також охарактеризовано основні досягнення сформованої на цих принципах української екологічної школи лісової типології. Відзначено питання, які потребують подальшого вирішення.

Ключові слова: лісова типологія; екологія; природа; класифікація; насадження; клімат; грунт; родючість.

\section{From making a classification of forests as ecosystems to the foundation of the Ukrainian school of thought in forest typology (On the $150^{\text {th }}$ anniversary of the birth of A. A. Krüdener)}

\section{Tkach', E. Migunova ${ }^{2}$}

The concept of forest as the unity of growing stock (living tree component), climate and soil, that is, as ecosystems, was first defined by A. A. Krüdener. The scientist has developed a classification of forests according to the fertility of the soils on which they grow, in the coordinates of their provision with nutrients and moisture. A.A. Krüdener proposed the first ecological classification of forests of European Russia on the principle of zoning its territory according to the main climatic indicators, with the subsequent division of forests within climatic zones and regions into types of stands according to the peculiarities of the petrographic composition and water regime of soils.

A.A. Krüdener, like G.F. Morozov, assigned the decisive role to the soil conditions in the formation of types of stands in the midst of homogeneous climatic areas, emphasizing that the main factor is not the soil itself as such, but the soil as a substrate, as a medium for plant growth. The scientist, in the process of intensive study of soils of different types of forest, revealed a close relationship of the nature of forest vegetation, not with the genetic types of soils, but with their fertility, and with their forest growth potential.

In so doing, to assess soil fertility, A.A. Krüdener used a new approach - the phytoindication method, that is, the vegetation, its composition and productivity were accepted as a criterion for the quality of soils.

In developing the classification of forests, A.A. Krüdener clearly adhered to the coordinate principle of soil quality assessment by the two main components of their fertility - the supply of nutrition and moisture, which became the determining factor in all subsequent classifications of the forest typology of the G.F. Morozov school. The total measure of fertility of the environment is the amount, proportion and distribution by seasons of limited environmental resources - heat, moisture and nutrition. Forest typological classification models are constructed in the coordinates of these resources - the climate grid in the coordinates of heat and atmospheric humidity, edaphic - in the coordinates of nutrition and soil moisture. Therefore, they can be used not only to classify forests, but also nature in general.

The article also describes the main achievements of the Ukrainian Ecological School of Forest Typology formed on these principles. The existing shortcomings and issues that need to be further addressed are noted.

Key words: forest typology; ecology; nature; classification; forest stand; climate; soil; fertility.

Viktor Tkach - Full Member of the Forestry Academy of Sciences of Ukraine, Corresponding Member of the National Academy of Agrarian Sciences of Ukraine, Doctor habil. (agricultural sciences), professor, director. Ukrainian Research Institute of Forestry \& Forest Melioration named after G. M. Vysotsky. Pushkinska str., 86, Kharkiv, 61024, Ukraine. Tel.: (057) 704-10-02. E-mail: Tkach@, uriffm.org.ua

Elena Migunova - Full Member of the Forestry Academy of Sciences of Ukraine, Doctor habil. (agricultural sciences), professor, Chief Research Fellow. Ukrainian Research Institute of Forestry \& Forest Melioration named after G. M. Vysotsky. Pushkinska str., 86, Kharkiv, 61024, Ukraine. Tel.: (057) 707-8071. E-mail: migunova-e-s@yandex.ua 